\title{
A BRIEF HISTORY OF \\ NATURAL RESOURCES \\ IN THE CYPRESS HILLS*
}

During the period when the dominant economy was the subsistence pattern of the Indian, man's impact on the land was minor. With the introduction of the white man's profit-oriented commercial system, however, this impact soon became significant. By 1879 the bison had been virtually eliminated from the Hills, the grizzly sometime in the 1890's, the elk by 1909, the cougar by about 1914, and the wolf by about 1925; in addition, the Hills were reported to be largely denuded of forest cover by about 1900 ... .

Today's tranquil vistas and peaceful surroundings belie the abundance of yesterday when the area possessed an animal life of great variety and plenty. It must have been a scene duplicated within our lifetime only in such places as the savannas of Africa ...

Concern over the wanton depletion of wildlife had surfaced by the late 1700's. David Thompson, Canada's premier geographer, perceived this situation in the case of the beaver as early as 1793 when he wrote: "Every intelligent man saw the poverty that would follow the destruction of the Beaver, but there were no chiefs to control it; all was perfect liberty and equality. Four years afterwards almost the whole of these extensive territories was denuded of Beaver ..." And regarding the bison, observant travellers in the United States in the 1830's were predicting its extermination ...

* Excerpts from: Canadian conservation and the Cypress Hills. By Carl Norbeck and J. Gordon Nelson. Prairie Forum Vol. 1, No. 1, p. 47-57. April 1976. The journal of the Canadian Plains Research Center, University of Regina, Regina, Sask.
With regard to the Cypress Hills, however, concern over bison depletion does not seem to have gained expression until the 1850's. In 1857 the plains Cree resolved in council that: "In consequence of the promises often made and broken by white men and half-breeds, and the rapid destruction by them of the buffalo ... they would not permit either the white men or half-breeds to hunt in their territory ...".

In 1877 this (Northwest Territories) government made a forlorn attempt to save the bison by passing an ordinance aimed at reducing the rate of slaughter. These regulations forbade the use of buffalo pounds, the wanton destruction of buffalo at any season, and the killing of animals under two years of age. The impossibility of enforcing these regulations, however, rendered this program ineffective also. Nonetheless, the recurrent theme of man over-exploiting the resources of the Hills now had, in an incipient form at least, the crucial counter-balance of conservation concern; and evidence of this concern had been demonstrated at the official level ...

For the settlers the resources of the Hills constituted a bounty of nature. The scope of their utilization was significant: "Journeys of up to sixty miles or more were made to haul timber. Twenty to forty wagons might daily pass along the main trails to the Hills". Furthermore, settlers from up to several townships away went to the benchland for hay to supplement their own supplies. In addition, dozens of irrigation projects sprang up in and around the Hills.

By the turn of the century, the unregulated demands placed upon these resources threatened their 
depletion on a scale comparable to that of wildlife. In 1893 the Superintendent of the North West Mounted Police in Maple Creek reported: "the supply (of timber) in the Hills is rapidly getting short, owing to the encroachments of settlers and destruction by fire"...

One of the first forest reserves established under the Dominion Forest Reserves Act of 1906 was the Cypress Hills Forest Reserve, which included a portion of the Hills forest resource ...

In 1930 the control of natural resources in Alberta and Saskatchewan was transferred to the provinces. In Alberta, the Cypress Hills Forest Reserve, initially managed under the Forest Reserves Act, eventually became today's Cypress Hills Provincial Park under the Provincial Parks and Protected Areas Act. In Saskatchewan, the Reserve, which comprised three blocks, became the Cypress Hills Provincial Forest (west block) and the Cypress Hills Provincial Park (centre block) under the Forest Act and the Provincial Parks and Protected Areas Act respectively. The east block was eventually designated a provincial community pasture.

Today ... both the Alberta and Saskatchewan governments are evaluating new Master Plan studies aimed at reassessing multiple-use priorities and optimizing park uses.

\section{FIRST RECORDS OF ROCKY MOUNTAIN JUNIPER IN SASKATCHEWAN}

V. L. HARMS, Fraser Herbarium, University of Saskatchewan, Saskatoon and DALE G. HJERTAAS, Ducks Unlimited, 5-1615 11th Ave., Regina, Sask.

During the last year two articles have appeared in the Blue Jay which have reported eastward range exten. sions of the Rocky Mountain Juniper (Juniperus scopulorum Sarg.) in Alberta. This erect shrub or small tree had long been known from the Waterton Lakes, Banff, and Crowsnest Pass areas of Alberta and most probably is present in a more or less continuous distribution between those Rocky Mountain sites. ${ }^{6}{ }^{5}$ Recently single isolated "trees" of Rocky Mountain Juniper were reported from two more eastern Alberta localities, the first at Glenwood near Cardston (Sec. 34, T 4, R 27 W 4th) and the second in the Oldman River valley just north of Lethbridge. ${ }^{4}$ Even more recently
(1975) and significantly another single isolated "tree" of this species was found near the southeastern corner of Alberta (SE 1/4 Sec. 5, T 1, R4 W 4 th) ${ }^{7}$

In the present article, we would like to report the recent discovery of naturally growing Rocky Mountain Junipers at three widely separated localities in southern Saskatchewan. The first finding of this species in Saskatchewan was by a group of University of Saskatchewan Biology students, including Marie Jasieniuk Wayne Renaud and K. J. Finley, who on May 25, 1975, discovered a tree a a location "somewhere southwest of Killdeer". These students, and in par. ticular, Marie Jasieniuk, recognizec 